BMJ Open

Sport \&

Exercise

Medicine

\title{
When women can be stars in sports, why is it so difficult in sports and exercise medicine research?
}

\author{
Kristina Fagher (D) ,' Evert Verhagen (D) ${ }^{2}$
}

To cite: Fagher K, Verhagen $\mathrm{E}$. When women can be stars in sports, why is it so difficult in sports and exercise medicine research? BMJ Open Sport \& Exercise Medicine 2022;8:e001218. doi:10.1136/ bmjsem-2021-001218

Accepted 21 December 2021

Check for updates

(c) Author(s) (or their employer(s)) 2022. Re-use permitted under CC BY-NC. No commercial re-use. See rights and permissions. Published by BMJ.

${ }^{1}$ Rehabilitation Medicine Research Group, Department of Health Sciences, Lund University, Lund, Sweden ${ }^{2}$ Amsterdam Collaboration on Health \& Safety in Sports, Department of Public and Occupational Health, Amsterdam Movement Sciences, Amsterdam UMC, University Medical Centres, Vrije Universiteit Amsterdam, Amsterdam, The Netherlands

Correspondence to Dr Kristina Fagher; kristina.fagher@med.lu.se
Watching the Olympic and Paralympics Games, we notice that both men and women achieve world-class performances. We see the world's best sports stars perform extraordinary athletic feats, regardless of who they are or where they come from. This equity was not always present at this world stage. For instance, until 1984, women were prohibited from running marathons during the Olympic Games. ${ }^{1}$ It may also surprise you that it was not until the 2012 London Games that all delegations sent a team consisting of both sexes.

Over the last decades, the Olympic and Paralympic movements have worked proactively for equity through leadership development and advocacy campaigns, leading to opportunities for women to also become sports stars. Nonetheless, it appears that we in Sports and Exercise Medicine (SEM) are falling behind. Although most of us aim for equity and equivalence, women are still heavily underrepresented in SEM research. In this editorial, we discuss existing concerns and possible solutions.

\section{CURRENT CONCERNS}

When we both reviewed our publications, we realised that we have published our papers with mostly male coauthors; our cumulative author lists consist of $67 \%(\mathrm{KF})$ and $74 \%(\mathrm{EV})$ male authors. We can also use our journal, BMJ Open Sports Eै Exercise Medicine, as an example. Even though our journal strive for equality, ${ }^{2}$ of all manuscripts published in 2021 to date, only $33 \%$ of all authors are women, and an equal percentage of women are first authors. Similar numbers are seen across SEM journals such as British Journal of Sports Medicine and American Journal of Sports Medicine and reflect the work that still needs to be done. Further, during the recent International Olympic Committee's World Conference on Prevention of Injury \& Illness in Sport later this year, five of the six keynote lectures were delivered by men. Similarly, the faculty of the 2022 Isokinetic Conference lists 25women against 158 men!
Moreover, there are few female Editors in Chief in any of the prominent SEM journals.

The mentioned inequalities are compounded by the fact that there are more men working in SEM than women. However, recent research showed that women-led papers are more likely to be rejected and less likely to be cited than those with corresponding male authors. ${ }^{3}$ Also, in an egalitarian country like Sweden, a very recent report (2021) shows that men and women with equal merits are scored unequally by reviewers when applying for nonblinded grants and senior academic positions. ${ }^{4}$ A previous report has also demonstrated that less than $20 \%$ of all research grants were given to women, despite the fact many women who applied were well qualified. The same report states that women need to perform 'twice' as much as men to be awarded a professor status. ${ }^{5}$ In summary, it is very clear and of utmost importance that, as a community, we react and act upon such gender discrimination.

\section{Yes, there are sex differences}

Despite the fact that more than half of the students at the undergraduate and postgraduate programmes in low-income and middle-income countries are women, only around $20 \%$ of all professors are women. ${ }^{6}$ Consequently, we are losing a large majority of well-educated women somewhere in their career path. We suggest that we should harness this potential and allow these students the opportunity to reach a higher academic position.

Still, we can't ignore that the start of an academic career often coincides with the period in life when we plan to have a family. In many countries, there is an ongoing debate regarding women's ability to coordinate the challenges of family life with those of an academic career. ${ }^{6}$ And yes, here rises an important sex difference! Even though we aim for equity and equivalence, we must face the fact that it is the woman who becomes pregnant, who has to carry a fetus, deliver a baby (a performance that can't be compared with any sporting achievement), 
and who has to undergo postpartum rehabilitation (a process that sometimes takes several years depending on several factors). All of these steps are sometimes associated with different treatments, medical procedures and psychological and physiological changes that often affect a woman both physiologically and mentally, which we sometimes forget in our equity striving society. Even though that we are moving towards more and more equal parenthood, there is still a profound risk that in the academic system, which is built on individual achievements, women may lose years of productivity compared with men if choosing to become pregnant.

To illustrate another argument, data show that married female scientists are almost always in dual-career relationships. ${ }^{6}$ In contrast, only half of the male scientists have partners who work full-time. There is also a risk that the $24 / 7$ work mentally of contemporary academics expose the female researcher to unreasonable workloads while having a family, which is supported by data showing that women aged 35-44 report the highest rates of burnout. ${ }^{7}$ Of course, the same phenomena may be present among male scientists in dual-career relationships. Therefore, we would also like to underpin the importance of both equity and equivalence within this topic.

\section{BE THE CHANGE}

We know that steps are being taken towards equity in SEM, and we are all part of a generation who have the norms and values that aim for equivalence. Yet, the process towards progress is slow, and we can't afford to lose another generation of brilliant women. It is important to remember that gender equality is not only a fundamental human right but also a necessary foundation for a peaceful, prosperous, and sustainable world. ${ }^{8}$ Therefore, we encourage all colleagues not to wait for change but to proactively support women and men equally in their pursuit of an academic career in SEM.

We could all immediately implement some suggestions to assist this cause, allowing women to reach their academic potential and allowing men to support their paths.

- Offer safe and long-term positions to younger academics. At the start of their academic career, they also often start building a family. With job security and some prospect, it is less likely that families choose the easy path of the 'traditional' household distribution.

- Encourage parenthood and treasure it as a merit. Both men and women should get the unbiased opportunity to support their family and their partner in pursuit of a career. This can be achieved by accepting and supporting equal parental leave, dual-career relationships, part-time work and affordable and subsidised quality childcare.

- Lead a team-based working environment in a problemsolving environment. In a complex and continuously developing and changing world, no person has the knowledge or capacity to produce all work. Working as a team allows colleagues, for example, to be home when the children are ill. Data from other sectors show that a team-based working environment can increase motivation, efficiency and health. ${ }^{9}$

- Avoid a 24/7 working mentality. Encourage work-free time and a healthy lifestyle instead. This will improve academic output while reducing risk of academic drop-out.

- Distribute work equally. With fewer female colleagues and increasing awareness of equality, there is a risk that women become overloaded. Do not distribute work equally across genders, and make sure female colleagues have the same workload as your male colleagues.

- Evaluate and reflect on why males have higher acceptance rates of scientific work. Consider gender blinded review processes.

- Encourage family-friendly conferences. The time with an accompanying wife is history!

- Engage, equip and empower young women to star in SEM research!

\section{Twitter Kristina Fagher @KristinaFagher and Evert Verhagen @evertverhagen}

Contributors KF contributed to the idea of the article, the concepts and writing. EV contributed with expertise, concepts and writing.

Funding KF has a post-doc position (D2021-0018) funded by the Swedish Research Council of Sports Sciences.

Competing interests EV is the editor in chief of BMJ Open Sports and Exercise Medicine, and KF is an Associate editor of para sport, qualitative research and equity.

Patient consent for publication Not applicable.

Provenance and peer review Not commissioned; externally peer reviewed.

Open access This is an open access article distributed in accordance with the Creative Commons Attribution Non Commercial (CC BY-NC 4.0) license, which permits others to distribute, remix, adapt, build upon this work non-commercially, and license their derivative works on different terms, provided the original work is properly cited, appropriate credit is given, any changes made indicated, and the use is non-commercial. See: http://creativecommons.org/licenses/by-nc/4.0/.

\section{ORCID iDs}

Kristina Fagher http://orcid.org/0000-0002-9524-7553

Evert Verhagen http://orcid.org/0000-0001-9227-8234

\section{REFERENCES}

1 Lovett C. Olympic marathon. Westport, CT: Greenwood Publishing Group, Inc, 1997.

2 BMJ Open Sports and Exercise Medicine. Diversity and inclusivity strategy. Available: https://blogs.bmj.com/bmjopensem/2021/08/30/ diversity-and-inclusivity-strategy/

3 Royal Society of Chemistry. Is publishing in the chemical sciences gender biased? 2019. Available: www.rsc.org/globalassets/04campaigning-outreach/campaigning/gender-bias/gender-bias-reportfinal.pdf

4 Andersson ER, Hagberg CE, Hägg S. Gender bias impacts topmerited candidates. Front Res Metr Anal 2021;6:594424.

5 Wennerås C, Wold A. Nepotism and sexism in peer-review. Nature 1997;387:341-3.

6 Mason MA, Wolfinger NH, Goulden M. Do babies matter? Gender and family in the ivory tower. New Brunswick, N.J: Rutgers University Press, 2013.

7 Norlund S, Reuterwall C, Höög J, et al. Burnout, working conditions and gender--results from the northern Sweden MONICA Study. BMC Public Health 2010;10:326.

8 United Nations. Sustainable development goals, 2021. Available: https://www.un.org/sustainabledevelopment/sustainabledevelopment-goals/ [Accessed 28 Aug 2021].

9 McDaniel SH, Salas E. The science of teamwork: introduction to the special issue. Am Psychol 2018;73:305-7. 